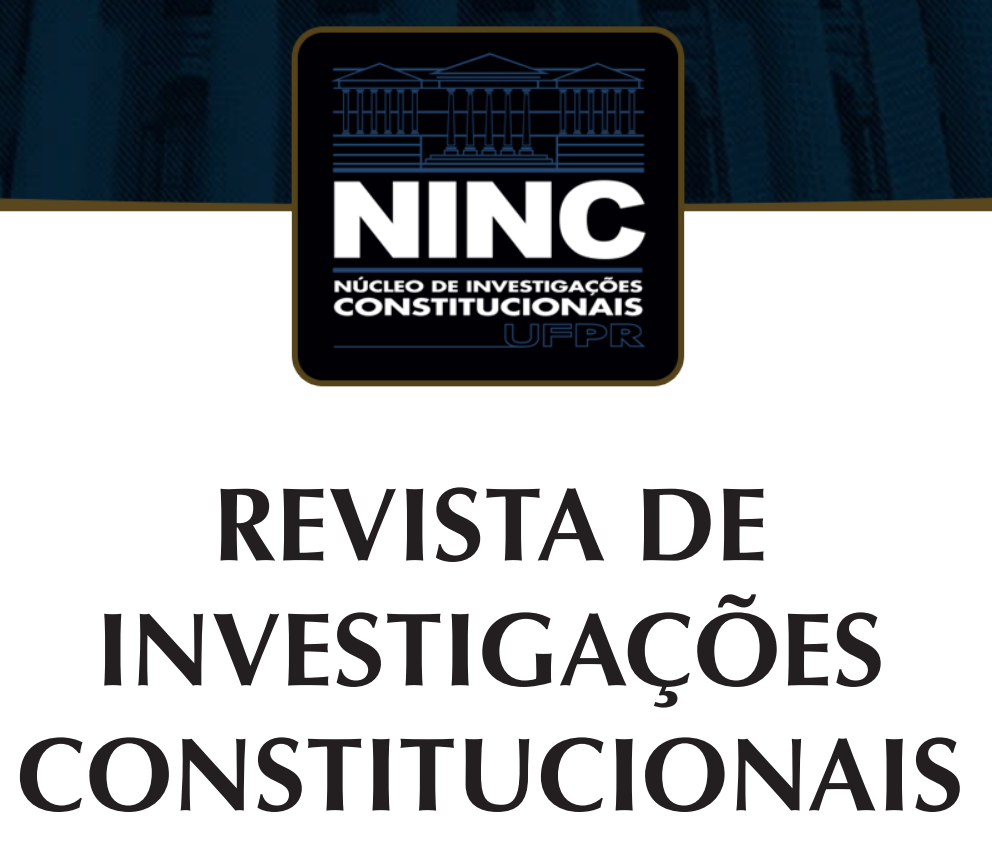

JOURNAL OF CONSTITUTIONAL RESEARCH

vol. 5 | n. 3 | setembro/dezembro 2018 | ISSN 2359-5639 | Periodicidade quadrimestral Curitiba | Núcleo de Investigações Constitucionais da UFPR | www.ninc.com.br 


\title{
Constitutionalism and rights protection in Mexico and Brazil: comparative remarks
}

\section{Constitucionalismo e proteção de direitos no México e no Brasil: observações comparadas}

\author{
FRANCISCA POU GIMÉNEZ \\ Instituto Tecnológico Autônomo do México (México) \\ francisca.pou@itam.mx \\ Recebido/Received: 13.08.2018 / August $13^{\text {th }}, 2018$ \\ Aprovado/Approved: 30.08.2018 / August 30 3018
}

\section{Abstract}

Comparative exercises between constitutional law in Brazil and in Mexico may seem destined to be exercises of identifying a reduced set of commonalities in an ocean of difference. The article, however, aims to suggest to what extent the opposite might be closer to the truth, and provide some sense of the amount of parallels between the two countries when viewed through constitutional lenses. Despite divergent paths of historical evolution in the XIX and the XX centuries, there are elements that confer to contemporary constitutional systems in Brazil and Mexico an air of commonality. The article underlines at least three of them: (i) commonalities in patterns of constitutional genesis and change; (ii) the existence of generous constitutional declarations of rights coupled with a varied assortment of rights-protecting channels in both places; and (iii) the existence in the two countries of old Supreme Courts with extensive jurisdictional menus and ample space for transformative action at their disposal. On the other hand, the main differences identified and analyzed in the article occur in the domain of rights

\section{Resumo}

Realizar uma análise comparativa entre o Direito Constitucional no Brasil e no México pode parecer ser uma tarefa destinada a ser um exercício de identificação de um conjunto reduzido de pontos comuns em um oceano de diferenças. $O$ artigo, no entanto, pretende sugerir que a posição exatamente oposta está mais próxima da realidade e assim fornecer alguma noção da quantidade de paralelos que podem ser traçados entre os dois países quando vistos através de lentes constitucionais. Apesar dos caminhos divergentes de evolução histórica nos séculos XIX e XX, há elementos que conferem aos sistemas constitucionais contemporâneos no Brasil e no México um ar de identidade. O artigo destaca pelo menos três deles: (i) semelhanças nos padrões de gênese e de reforma constitucional; (ii) a existência de generosas declarações constitucionais de direitos, combinadas com uma variedade de instrumentos de proteção desses direitos; e (iii) a existência nos dois países de Supremas Cortes antigas e com extensos "menus jurisdicionais" e amplo espaço à sua disposição para atuar de um modo transformador na sociedade. Por outro lado, as principais

Como citar esse artigo/How to cite this article: POU GIMÉNEZ, Francisca. Constitutionalism and rights protection in Mexico and Brazil: comparative remarks. Revista de Investigações Constitucionais, Curitiba, v. 5, n. 3, p. 233-255, set./dez. 2018. DOI: DOI: 10.5380/rinc.v5i3.60972.

"Professor of Law at Instituto Tecnológico Autônomo do México (Ciudad de México, México). JSD and LLM at Yale University (New Haven, United States of America). Degree of Law at Pompeu Fabra University (Barcelona, Spain). E-mail: francisca.pou@itam.mx. 
protection and include the system of judicial enforcement of rights and the public profile of the two Supreme Courts.

Keywords: constitutionalism; Comparative Law; Brazil; Mexico; Supreme Court. diferenças identificadas e analisadas no artigo ocorrem no domínio da proteção de direitos e incluem o sistema de execução judicial e o perfil público das duas Supremas Cortes.

Palavras-chave: constitucionalismo; direito comparado; Brasil; México; Suprema Corte.

\section{CONTENTS}

1. Introduction; 2. Constitutional genesis and constitutional change; 3. Generous rights declarations and rights-protecting devices; 4. Two big, monarchical Supreme Courts; 5 . A dis-analogy: rights revolution versus rights frustration; $\mathbf{6}$. Conclusion; 7 . References.

\section{INTRODUCTION}

Doing comparative analysis between Mexico and Brazil is a thrilling prospect. At the outset, the two countries look like an odd couple - the surprising confluence of two Latin American giants with very little in common. They are far removed from one another in popular imagination, and even geographically, and both enjoy a tradition of thinking of themselves as self-standing societies — as almost separated "continents" within a wider Latin American space they are largely unaware of in daily life. The reading of Octavio Paz's famous portrayal of the Mexican soul, the Labyrinth of Solitude, already suggests that much, ${ }^{1}$ and at a more pedestrian level there is little doubt that in Mexico many dimensions of life unfold with scarce external horizons: South America feels far removed, the United States represent the "other" one should ward off, and Central America and the Caribbean are systematically ignored. With regards Brazil, Roberto Unger eloquently evocates an analogous idea in Democracy Realized when identifying the country as one of the very few that enjoy the size and the social and cultural resources to "imagine itself as something of a world unto itself rather than as a satellite to some other system".2

Comparative exercises between Brazil and Mexico seem therefore destined to be exercises of identifying a reduced set of commonalities in an ocean of difference. In this exploratory contribution, I want to suggest to what extent the opposite might be closer to the truth, and provide some sense of the amount of parallels between the two countries when viewed through constitutional lenses - well beyond what would be expected from their naturally being two contemporary Latin American democracies.

\footnotetext{
1PAZ, Octavio. El laberinto de la soledad. Mexico City: Fondo de Cultura Económica, 1994.

${ }^{2}$ UNGER, Roberto Mangabeira. Democracy realized. The progressive alternative. London: Verso, 1998.
} 
Where these commonalities come from, and what sort of underlying social and historical factors explain them, are questions that remain beyond the scope of the analysis. The idea is more simply to illustrate some of them, to subsequently develop an exercise in "most similar cases" comparison, ${ }^{3}$ identifying a few, remarkable differences, in an ocean of resemblance.

Despite divergent paths of historical evolution in the XIX and the XX centuries -Brazil, for instance, was for long a monarchy after declaring Independence, and in the XX century it undergone periods of military rule that are absent in Mexico- there are elements that confer to contemporary constitutional systems in Brazil and Mexico an air of commonality. I will underline three of them: commonalities in patterns of constitutional genesis and change; the existence of generous constitutional declarations of rights coupled with a varied assortment of rights-protecting channels in both places; and the existence in the two countries of old Supreme Courts with extensive jurisdictional menus and ample space for transformative action at their disposal.

The differences I will identify occur in the domain of rights protection and include at least the following two features: first, access to justice and judicial enforcement of rights - particularly social, cultural and environmental rights - has been clearly more extensive in Brazil than in Mexico. And second, rights protection in the two countries has been led by two Supreme Courts that, while sharing many common elements in terms of institutional design and internal mode of operation, have progressively developed openly different public profiles. While the Brazilian Supreme Federal Tribunal has abandoned its initial "professional" outlook to become an activist body that does not refrain from addressing the hottest political issues of the day, the Mexican Supreme Court has not culminated any sort of "rights revolution" and maintains a contained public profile.

Our cursory comparative exercise invites inquiry in several directions, which in this occasion will be merely hinted at. First, and most obviously, at the level of institutional design: although the best explanations about rights protection and judicial behavior are grounded in multivariate theoretical frameworks and require extensive research, there are elements which seem to be clearly making a difference, like the existence in Brazil of specific rights protecting writs and collective actions, or the role displayed by agents of the Ministerio Público and other public servants in supporting the judicialization of claims -in comparison with the impeding role of the amparo in Mexico, coupled with the absence of supporting structures. On a much abstract level, the joint analysis of commonality and specific difference may help ground diagnoses

\footnotetext{
${ }^{3}$ I rely on the well-known contrast between two comparative methodologies ("most similar cases" and "most different" cases), initially distinguished by John Stuart Mill. For further explanation and examples, see HIRSCHL, Ran. On the blurred methodological matrix of comparative constitutional law. In: CHOUDHRY, Sujit. (ed.). The migration of constitutional ideas. New York: Cambridge University Press, 1995, p. 47-53.
} 
about the main weaknesses of the respective constitutional systems. Thus, while both in Mexico and Brazil there are problems of "input" legitimacy - since constitution -making and constitutional amendment have been largely led by elite negotiationin Brazil this has been probably compensated by the "output" legitimacy associated to, among other things, a robust practice of judicial rights protection. This source of output legitimacy is not available in Mexico. In Brazil, the danger might rather come from the sustainability of the model, given the seemingly non-balanced role that the Supreme Federal Tribunal (or even its individual Justices) plays in the constitutional system.

\section{CONSTITUTIONAL GENESIS AND CONSTITUTIONAL CHANGE}

In both Brazil and Mexico the current Constitution is the product of negotiations and concessions between different groups, rather than the product of broad popular mobilizations marking a moment of strong political discontinuity - like the ones that gave rise to the constitutions of Colombia, Bolivia or Ecuador. In the case of Brazil, after a period of military rule, the opposition won the 1985 presidential indirect election, and a constituent assembly was elected and started works in 1987. This assembly, however, entertained considerable bonds with the past. Thus, the same decrees that summoned it made it clear that amnesty for the crimes of the past was untouchable, and the assembly was actually composed of senators and deputies, some of whom had been elected during the authoritarian regime and continued to operate as ordinary legislators even after the new constitution entered into force. ${ }^{4}$ Their center or center-right affiliations had therefore some weight, together with the views exposed by members of the party that had been the main site of opposition during the previous regime. The former opposition had certainly control of the thematic and systematization committees in charge of producing the text of the constitution - whose content was enriched by a process of broad popular participation that allowed citizens to present popular amendments and individual communications - but at one point conservative political forces changed the rules of procedure to increase their control of the product. ${ }^{5}$ The 1988 constitution — which was not submitted to popular referendum ${ }^{6}$ - is therefore consistent and progressive in many respects, but derives of a deep mix of past and

\footnotetext{
${ }^{4}$ SILVA, Virgílio Afonso da. The Constitution of Brazil. A Contextual Analysis. Oxford: Hart Publishing, 2019 (forthcoming). p. 39; 38. All page numbers refer to the manuscript version, on file with author.

${ }^{5}$ SILVA, Virgílio Afonso da. The Constitution of Brazil. A Contextual Analysis. Oxford: Hart Publishing, 2019 (forthcoming). p. 16, n. 8.

${ }^{6}$ There was, however, a referendum in 1993 that asked citizens about the form of government (parliamentarism versus presidentialism) and form of state (monarchy versus republic). The latter options were supported by large majorities. SILVA, Virgílio Afonso da. The Constitution of Brazil. A Contextual Analysis. Oxford: Hart Publishing, 2019 (forthcoming). p. 15.
} 
present channeled through a contorted procedure that gave space and negotiation power to many different groups.

Subsequently, higher-lawmaking in Brazil has been advanced through elite-driven negotiation within the confines of the constitutional amendment formula. According to Article 60, proposals to amend the constitution must be discussed and voted twice in each House and supported by a three-fifth vote in very round -though, in contrast to what happens in Mexico, the States of the Federation remain outside the amendment process. There are moreover material limits to reform - since amendments cannot attempt to change the federal system, the separation of powers, individual rights, or the system of direct and universal elections - as well as temporal conditions - since amendments cannot be discussed in some circumstances, and rejected proposals cannot be reconsidered in the same year. Yet despite this formal rigidity, political elites in Brazil have managed to pass 99 amendments to date. Scholars agree that amendments have left the constitutional core untouched, ${ }^{7}$ but there is no wonder that political and social elites have found in the constitution a pretty flexible carrier of their evolving political agendas. ${ }^{8}$ The Supremo Tribunal has asserted its power to review the constitutionality of constitutional amendments (even ex ante, before their formal passing), thus slowing down change and further securing institutional control of higher-level legal change. ${ }^{9}$

In Mexico, the Constitution was initially a product of the Mexican revolution. Albeit the group that controlled the Constitutional Assembly in Querétaro represented a moderate section of the revolutionaries, the text nonetheless included part of the more radical claims other groups had endorsed in previous conventions. ${ }^{10}$ But in the course

\footnotetext{
${ }^{7}$ BENVINDO, Juliano Zaiden. The Brazilian Constitutional Amendment Rate: A Culture of Change? International Journal of Constitutional Law Blog. Available at: http://www.iconnectblog.com/2016/08/the-brazilianconstitutional-amendment-rate-a-culture-of-change/ Accessed on: 11 Oct. 2017 (noting that amendments have not affected the constitutional core) and SILVA, Virgílio Afonso da. The Constitution of Brazil. A Contextual Analysis. Oxford: Hart Publishing, 2019 (forthcoming). p. 15 (noting that the only part that has been strongly affected is the one where state intervention in the economy is regulated).

${ }^{8}$ See BARBOSA, Leonardo Augusto de Andrade. Legislative Process and Constitutional Change in Brazil: On the Pathologies of the Procedure for Amending the 1988 Constitution. In: ALBERT, Richard; BERNAL, Carlos; BENVINDO, Juliano Zaiden (eds.). Constitutional Change and Transformation in Latin America. Oxford: Hart Publishing, 2019 (forthcoming) (describing with detail Parliamentary dynamics around amendment, including the practice of passing partial amendments) and COSTA, Alexandre Araújo; ASSUNÇÃO, Guilherme Sena de. On the Limits of the Supermajority Rule: The Brazilian Experience on Using Constitutional Amendments to Circumvent the System of Checks and Balances. In: ALBERT, Richard; BERNAL, Carlos; BENVINDO, Juliano Zaiden (eds.). Constitutional Change and Transformation in Latin America. Oxford: Hart Publishing, 2019 (forthcoming) (describing how constitutional amendment is used to circumvent the system of checks and balances built in ordinary lawmaking).

${ }^{9}$ On judicial review of constitutional amendments in Brazil, see SALGADO, Eneida Desiree; CHAGAS, Carolina Alves das. The Judicial Review of Constitutional Amendments in Brazil and the Super-Countermajoritarian Role of the Brazilian Supreme Court. In: ALBERT, Richard; BERNAL, Carlos; BENVINDO, Juliano Zaiden (eds.). Constitutional Change and Transformation in Latin America. Oxford: Hart Publishing, 2019 (forthcoming).
}

${ }^{10}$ MARVÁN LABORDE, Ignacio. Cómo hicieron la Constitución de 1917. Mexico City, CIDE, 2017. p. 168-186. 
of the century, constitution-making fell progressively in the hands of the hegemonic party elites. As we have described elsewhere, when political dynamics slowly made room for political pluralism in the decades of the $80 \mathrm{~s}$ and $90 \mathrm{~s}$, and in spite of the fact the amendment formula requires half of State legislatures to ratify the decisions adopted by the two chambers of the Federal Congress, the constitutional amendment rate increased exponentially. ${ }^{11}$ Increase in political plurality did not translate into an increase of actual constitutional rigidity, but rather inaugurated a scenario in which amending the Constitution meant space for negotiation -and hence for political inclusion, at the level of political parties. ${ }^{12}$ For many years, hyper-reformism consequently helped Mexico's peacefully transition to democracy. ${ }^{13}$ Over time, however, its effects became increasingly problematic. On the one hand, the succession of piecemeal, non-systematic changes made the text increasingly heterogeneous, disorganized, and even openly contradictory, thus damaging the function of the constitution as a legal norm; on the other, amendment soon started to be taken by politicians as little more than legislation by other means - a dynamics the Supreme Court has not impeded, in refraining from reviewing the constitutionality of amendments - despite the fact some of the reforms, in contrast with the situation in Brazil, have been substantively far-reaching. ${ }^{14}$ The end -result is that people is little acquainted with the actual contents of an extremely long and obscure text, authored by a distant and non-diverse Assembly of the past, which is modified continuously by the political elites without any special deliberation -often without society even noticing it.

As we can see, both Mexico and Brazil are, then, democracies that operate under Constitutions that have operated as flexible frameworks of mutual accommodation between different groups -including, most notably, political and social elites. Both constitutions face, to some degree, deficiencies in terms of original "input" legitimacy ${ }^{15}$ and

\footnotetext{
${ }^{11}$ CASAR, María Amparo; MARVÁN, Ignacio. (eds.). Reformar sin mayorías. La dinámica del cambio constitucional en México 1997-2012. Mexico City: Taurus, 2014. p. 29-36.

${ }^{12}$ CASAR, María Amparo; MARVÁN, Ignacio. (eds.). Reformar sin mayorías. La dinámica del cambio constitucional en México 1997-2012. Mexico City: Taurus, 2014. As these authors document, from 1997 to $2014,83 \%$ of constitutional amendments were positively voted by the three leading parties.

${ }^{13}$ POU GIMÉNEZ, Francisca; POZAS-LOYO, Andrea. Are Constitutional Amendment and Judicial Review Substitutes? Unexpected Lessons from Mexico and Brazil. Paper presented at the Law and Society Annual Meeting, Mexico City, 2017.

${ }^{14}$ POU GIMÉNEZ, Francisca; POZAS-LOYO, Andrea. Are Constitutional Amendment and Judicial Review Substitutes? Unexpected Lessons from Mexico and Brazil. Paper presented at the Law and Society Annual Meeting, Mexico City, 2017.

${ }^{15}$ I take inspiration in the distinction between input and output legitimacy as used in TSCHORNE, Samuel I. The "legitimacy crisis" and the "constitutional problem" in Chile: what is left? Paper presented at Seminario en Latinoamérica de Teoría Constitucional y Política 2018, San Juan de Puerto Rico, 2018. I use it with some licenses, as for Tschorne, questions of input legitimacy refer to questions of democratic representation and questions of output legitimacy to state problem-solving capacity.
} 
preside over scenarios in which rigidity is a mirage. ${ }^{16}$ In Brazil, because the Constitution was the product of a somewhat contorted procedural path, because it included at least implicit concessions to sectors that had been powerful during the dictatorship, and because it has been subsequently amended with ease by Brazilian politicians in interaction with the Supreme Court, without direct participation of the citizenry. In Mexico, because the initial constitution-making moment is one hundred years away, and because the content of the Constitution is at this point an obscure magmatic substance that politicians manipulate at their will. In both countries, the legitimacy of the Constitution will be importantly dependent on the outcomes (as opposed to inputs); there will have to be "legitimacy of exercise" to compensate for deficits in "legitimacy of origin". Virgílio Afonso da Silva gestures at this distinction when he remarks that the Brazilian constitution-making process has both weaknesses and undeniable merits, but that the relevant issue is, in any case, whether this affects the legitimacy of the constitution itself. ${ }^{17}$ In comparative inquiries about the two countries, in sum, it will be interesting to monitor in what ways the arguable "imperfections" of constitutional origins are compensated by what the Constitution is perceived to deliver in terms of results.

\section{GENEROUS RIGHTS DECLARATIONS AND RIGHTS-PROTECTING DEVICES}

The Brazilian declaration of rights is formally compact, but dense and extensive -only Article 5, focused on freedom-based rights, contains 78 clauses - and it incorporates many of the novelties that would subsequently enter Latin American constitutional declarations of rights in the following decades. Most rights are found in Heading II ("Fundamental Rights and Guarantees"), which lists civil, political and social rights, but in Heading VIII ("Social Order"), there are additional provisions that impinge on the same or other rights - like the right to an ecologically balanced environment, rights of indigenous people, elderly people or cultural rights. ${ }^{18}$ Most rights clauses are reasonably detailed, and include instructions to public authorities addressed to secure actual action in pursuance of real transformation. Equality-related provisions, for instance, include specific, action-requiring language, thus pointing to a model of substantive equality, with a particular concern for race and gender (though less for sexual orientation or the rights of migrants); traditional labor rights and other social rights are gene-

\footnotetext{
${ }^{16}$ VELASCO, Mariana. Mexico's Constitutional Entrenchment Mirage: The Political Sources of Hyper-Reformism. In: ALBERT, Richard; BERNAL, Carlos; BENVINDO, Juliano Zaiden (eds.). Constitutional Change and Transformation in Latin America. Oxford: Hart Publishing, 2019 (forthcoming).

${ }^{17}$ SILVA, Virgílio Afonso da. The Constitution of Brazil. A Contextual Analysis. Oxford: Hart Publishing, 2019 (forthcoming). p. 40.

${ }^{18}$ SILVA, Virgílio Afonso da. The Constitution of Brazil. A Contextual Analysis. Oxford: Hart Publishing, 2019 (forthcoming). p. 16.
} 
rously listed; provisions on the environment, in the various sections of Article 225, set forth a consequential list of government duties; provisions on indigenous communities' rights are also important and inaugurated a regional cycle that finds continuity in the very robust provisions of the Constitutions of Ecuador and Bolivia. ${ }^{19}$

The 1988 constitution includes also a clause according to which "the rights and guarantees established in this Constitution shall not exclude others derived from the regime and principles adopted by it, or from international treaties to which the Federative Republic of Brazil is a party" (Art 5 \$2). Besides echoing the US tradition of guaranteeing un-enumerated rights, this clause has been crucial to align Brazil with a phenomenon that now traverses Latin American constitutionalism: the opening to international sources of rights, in particular the Inter-American system. ${ }^{20}$ While at the beginning the Supreme Tribunal did not take the wording of this article as a reason to change its views on the hierarchical position of treaties, after a 2004 amendment declared that the treaties approved following certain conditions would be equivalent to constitutional amendments, the Tribunal eventually clarified the situation that now prevails: post-2004 treaties would enjoy constitutional status (if approved through the prescribed procedure), and pre-2004 ones supra-legal status. ${ }^{21}$

The Mexican declaration of rights has attained a seemingly analogous end-result through a different pattern of evolution. Although the enshrinement of a number of social rights made of the 1917 constitution a path-breaking document, it naturally missed, for several decades, many of the novelties of post-war constitutionalism. The decade of the 1990s and 2000s were then dominated by the intermittent, "retail" addition of fundamental rights to the Constitution - at the impulse of politicians that saw short-term legitimacy gains in doing so, and little costs, given the scarce degree of actual enforcement these rights obtained. The declaration of rights was object of a more consequential, "wholesale" reform in 2011. The reform declares rights included in the treaties ratified by Mexico to be part of the bill of rights, enshrines interpretive principles like universality, indivisibility, interdependence, progressivity, and pro persona, and includes the canonical list of State duties regarding rights, as have been developed

\footnotetext{
${ }^{19}$ For a comprehensive, extremely informative overview of the constitutional bill of rights, with references to legislation and Supreme Court interpretations, see SILVA, Virgílio Afonso da. The Constitution of Brazil. A Contextual Analysis. Oxford: Hart Publishing, 2019 (forthcoming). p. 137-222. On the place of the Brazilian constitution in Latin American cycles of pluralist constitutionalism, see YRIGOYEN FAJARDO, Raquel Z. The panorama of pluralist constitutionalism: from multiculturalism to decolonization. In: RODRÍGUEZ-GARAVITO, César. (ed.). Law and Society in Latin America. A New Map. New York: Routledge, 2015.

${ }^{20}$ For an overview, see BOGDANDY, Armin von. MAC-GREGOR, Eduardo Ferrer; ANTONIAZZI, Mariela Morales; PIOVESAN, Flávia (eds.); SOLEY, Ximena (managing ed.). Transformative Constitutionalism in Latin America: The Emergence of a New lus Commune. Oxford: Oxford University Press, 2017.

${ }^{21}$ BOGDANDY, Armin von. MAC-GREGOR, Eduardo Ferrer; ANTONIAZZI, Mariela Morales; PIOVESAN, Flávia (eds.); SOLEY, Ximena (managing ed.). Transformative Constitutionalism in Latin America: The Emergence of a New lus Commune. Oxford: Oxford University Press, 2017, p. 186-188.
} 
in international human rights law. The transformative impact of the reform is, however, somehow curbed by the fact the Constitution contains provisions at odds with those found in the treaties that the Supreme Court has declared to prevail22 and because, after decades of un-ending constitutional amendment, many rights provisions - due process rights would be a case in point - are extremely contorted and almost impossible to apprehend by citizens.

Both the Constitution of Brazil and Mexico include, in short, generous declarations of rights. They are documents open to international human rights law that allow for the sort of integrative rights-protective interaction the Inter-American Court of Human Rights is so energetically promoting in the region. ${ }^{23}$ Both Constitutions evince a concern for efficacy, though in Brazil the declaration is more transparent and more internally coherent than in Mexico, where in any case the presence of last-generation legal notions may boost substantive impact. Admittedly, in this rubric the two countries simply share in a feature common to all Latin America contemporary constitutions ${ }^{24}$. An additional, complementary feature that is also common to regional constitutionalism (and singularizes it in the comparative scenario) is the inclusion of numerous rights -protecting channels in the context of hybrid systems of judicial review. ${ }^{25}$

The Brazilian constitution sets forth a multifaceted system of judicial review. Its first component is abstract review, Kelsenian style, with presence in the country from 1946 , operating at the moment through four different channels: the direct action of unconstitutionality, the direct action of unconstitutionality for omission, the declaratory action of constitutionality and the allegation of breach of fundamental precept. ${ }^{26}$ The second dimension of the system is decentralized or diffuse review, which exists since

\footnotetext{
${ }^{22}$ On this ruling, see SILVA GARCÍA, Fernando. Derechos humanos y restricciones constitucionales: ¿reforma constitucional del futuro vs. interpretación constitucional del pasado? (comentario a la CT 293/2011 del Pleno de la SCJN). Cuestiones constitucionales, n. 30, p. 251-272, 2014, and POU GIMÉNEZ, Francisca; RODILES, Alejandro. Mexico. In: PALOMBINO, Fulvio (ed.). Duelling for Supremacy: International Law vs. National Fundamental Principles. Cambridge: Cambridge University Press, 2019 (forthcoming).

${ }^{23}$ BOGDANDY, Armin von. MAC-GREGOR, Eduardo Ferrer; ANTONIAZZI, Mariela Morales; PIOVESAN, Flávia (eds.); SOLEY, Ximena (managing ed.). Transformative Constitutionalism in Latin America: The Emergence of a New lus Commune. Oxford: Oxford University Press, 2017.

${ }^{24}$ UPRIMNY, Rodrigo. The recent transformation of constitutional law in Latin America. Trends and challenges. In: RODRÍGUEZ-GARAVITO, César. (ed.). Law and Society in Latin America. A New Map. New York: Routledge, 2015.

${ }^{25}$ UPRIMNY, Rodrigo. The recent transformation of constitutional law in Latin America. Trends and challenges. In: RODRÍGUEZ-GARAVITO, César. (ed.). Law and Society in Latin America. A New Map. New York: Routledge, 2015.

${ }^{26}$ The first one is the most close to a classic Kelsenian abstract review; it is available only to certain state actors and delivers rulings with erga omnes. The second is also abstract, but is particularly addressed to combat state inaction that damages the effectiveness of the Constitution. The third one - the declaratory action- allows the Supremo Tribunal to unify legal interpretation when lower courts hold different criteria about the constitutionality or unconstitutionality of legislation. The fourth, introduced in 1999, is functionally almost indistinguishable from the first one, though it allows examination of municipal laws and statutes enacted before the 1988 constitution. See SILVA, Virgílio Afonso da. The Constitution of Brazil. A Contextual Analysis. Oxford:
} 
1890, when the judiciary of the First Republic was created, following US parameters. Any Brazilian judge can set aside a statute if it believes it violates the constitution. These channels are instrumental to the guarantee of all constitutional contents, among them fundamental rights. Yet the 1988 Constitution includes also several writs - which may be filed before any judge - that offer specific protection before rights violations: the "mandado de segurança", de "mandado de injunçao", the habeas corpus, the habeas data and the popular action. ${ }^{27}$ The Constitution has also regard for what it calls "functions essential to justice", which include the Public Ministry, Public Advocacy, the legal profession and the Public Defender's Office. ${ }^{28}$

In Mexico, the procedural menu is even broader, since the Constitution makes room for three modalities of review: centralized, semi-centralized and diffuse. As in Brazil, abstract review was an addition of the second half of the XX century, and is exercised in a channel called action of unconstitutionality - though when resolving conflicts of jurisdiction between States, Federation and municipalities, or between different power branches, in a channel called "constitutional controversy", the Supreme Court can also invalidate statutes with erga omnes effects. Decentralized or diffuse review was from the beginning a textual possibility, but the XX century was dominated by an interpretation of the Supreme Court that made judicial review the exclusive province of the Federal Judiciary. In 2011, the Court changed that interpretation and admitted diffuse review back into the country. ${ }^{29}$ In any event, constitutional enforcement in Mexico is dominated by what occurs in a channel of semi-centralized review: the writ of amparo.

The amparo was first included in the State of Yucatán constitution by mid XIX century and, from 1847 onwards, in all federal Mexican constitutions. It is therefore an extremely old institution. It may be filed before federal judges before any act of public authority: administrative acts, statutes, regulations, judicial rulings. It fulfills, in theory, the functions displayed by the Brazilian specific writs, in addition to operate as a sort of cassation device, since it allows federal judges to review if applicable norms have been correctly applied in the case at hand. The institution grew tremendously in complexity after decades of operating as an ordinary third stage with regards almost all state and federal judicial proceedings. It is an institution mortgaged by path dependencies coming from very distant times, almost impossible to use without the help of a

Hart Publishing, 2019 (forthcoming), p. 116-123, and ROSENN, Keith S. Procedural Protection of Constitutional Rights in Brazil. The American Journal of Comparative Law, v. 59, n. 4, p. 1009-1050, 2011, p.1039-1047.

${ }^{27}$ ROSENN, Keith S. Procedural Protection of Constitutional Rights in Brazil. The American Journal of Comparative Law, v. 59 n.4, p. 1009-1050, 2011, p. 1013-1033.

${ }^{28}$ SILVA, Virgílio Afonso da. The Constitution of Brazil. A Contextual Analysis. Oxford: Hart Publishing, 2019 (forthcoming). p. 133 and ff.

${ }^{29}$ See Mexican Supreme Court, Varios 912/2010, decided July 14, 2011. Available at: <https://www.sitios.scjn. gob.mx/codhap/sites/default/files/engrosepdf_sentenciarelevante/RADILLA\%20VARIOS\%20912-2010.pdf/>. Accessed on: 11 Oct. 2017. 
specialized lawyer. The constitutional reform of 2011 addressed the amparo in addition to redesigning the bill of rights: standing requirements were softened, denounce of collective rights affectations was made possible, and the possibility of conferring erga omnes effects to certain determinations, through a special vote in the Supreme Court, was introduced. With the help of the interpretive principles now included in Article 1 of the Constitution, one would have expected these changes to boost rights enforcement. But as we will later see, changes have not substantially widened access to justice for those that need it most.

\section{TWO BIG, MONARCHICAL SUPREME COURTS}

When Mexican revolutionaries gathered in Querétaro to amend the 1857 Constitution and ended up by enacting a new one, the judiciary was not a priority. In their understanding, the revolutionary program was to be executed under the lead of the Executive and the Legislative, not the Judiciary. ${ }^{30}$ While they placed labor and administrative courts under the orbit of the Executive - they were certainly important for the execution of the political program - they left untouched the judicial structure of the previous century, modeled after the US system, composed of District Judges, Circuit Courts, and a Supreme Court at the top. The worries all along were accumulation of pending suits - something that led to the creation of Collegiate Circuit Courts in the 1950 s - but other than that, the federal judiciary stayed pretty stable until the 80 s and 90s, when steps were taken to transform the Court into "a true Constitutional Tribunal". Thus, in a 1988 reform, the resolution of judicial amparos was transferred to the Collegiate Courts, allowing review before the Supreme Court only under specific conditions, and in the important 1994 reform — which created the Judiciary Council, in line with regional developments - abstract review was introduced and further measures were taken to diminish the caseload of the Court to make it focus on the most important constitutional issues.

In Brazil, the Supreme Federal Tribunal is also an institution with deep continuities with the past. It was created in 1890, by a decree, at the end of the Empire. The republican Constitution of 1891 ratified the institution, in a system structurally modeled, as in Mexico, largely after the US one. As Silva underlines, "note of the several institutional and constitutional breaks, regime changes, coups d'état and institutional and constitutional crisis has ever directly and immediately affected the composition of the Brazilian Supreme Court". ${ }^{31}$

${ }^{30}$ COSSÍO DÍAZ, José Ramón. Sistemas y modelos de control constitucional en México. Mexico City: IIJ UNAM, 2013.

${ }^{31}$ SILVA, Virgílio Afonso da. The Constitution of Brazil. A Contextual Analysis. Oxford: Hart Publishing, 2019 (forthcoming), p. 102. 
At the level of institutional design, the amount of similarities between the two Courts is remarkable. Both institutions are composed of eleven Justices. The Mexican ones are appointed for 15 years while the Brazilians have life tenure -although, as all other public servants, they must mandatorily retire at 65 . The appointing procedure involves in both places collaboration between the President and the Senate - with more Presidential intervention in Mexico, since she presents to the Senate a shortlist of three candidates among whom to choose. Both in Mexico and Brazil the Court decides in Plenary or in two Panels composed of five Justices each — specialized by subject matter in Mexico, not in Brazil - although in Brazil many decisions are actually adopted by a single Justice. ${ }^{32}$ The President of the Court is elected in both cases by the Justices themselves (for two years in Brazil and for four in Mexico), though in Brazil an informal rule of rotation in favor of the senior Justice is at work - something that liberates the Brazilian Court from the background battles and "campaigns" that infect its Mexican peer when the time to replace the President arrives. In both Courts the President participates (and directs the discussion) in the Plenary and does not sit in Panels. The Brazilian President can decide alone more issues than its Mexican pair and, in contrast to the latter, can exercise a casting vote. Both Courts have an unmatched influence in well-funded federal judiciaries, ${ }^{33}$ but the Mexican Court clearly concentrates more power: its President is simultaneously the President of the Judiciary Council, it does not share space with other apex courts - while in Brazil the 1988 Constitution created the Superior Court of Justice - and its formal and informal influence on lower judges is enormous. While in Brazil no doctrine of binding precedent was traditionally in place, Mexico has a formalized system of precedents that lower judges cannot disregard on pain of sanction by the Judiciary Council. The fact that before 1994 lower judges and magistrates were selected by Justices was among the facts that contributed to install a feudalistic dynamics in the Mexican judiciary. ${ }^{34}$

Jurisdiction is extremely broad in both cases. The Brazilian Supreme Tribunal culminates the diffuse review tier and has ordinary and extraordinary appellate jurisdiction, together with original jurisdiction concerning certain specific matters or persons. It then concentrates, of course, all what concerns the four channels of abstract review, and resolves some additional issues — such as "complains" in case of non-compliance

\footnotetext{
${ }^{32}$ ARGUELHES, Diego Werneck; RIBEIRO, Leandro Molhano. 'The Court, it is I'? Individual judicial powers in the Brazilian Supreme Court and their implications for constitutional theory. Global Constitutionalism, v. 7, n. 2, p. 236-262, 2018.

${ }^{33}$ ROSENN, Keith S. Recent Important Decisions by the Brazilian Supreme Court. The University of Miami Inter-American Law Review, v. 45 n. 2, p. 297-334, 2013, p. 300.

${ }^{34}$ POZAS-LOYO, Andrea; RIOS FIGUEROA, Julio. Anatomy of an Informal Institution: Patronage Networks and the 'Gentlemen's Pact' in the Mexican Federal Judiciary, 1917-1994. International Political Science Review. vol. 39, n. 5, p. 647-661, 2018.
} 
with its rulings. ${ }^{35}$ In Mexico the Supreme Court decides actions of unconstitutionality, constitutional controversies (horizontal and vertical conflicts of jurisdiction), contradictions of thesis (when Collegiate courts decide the same issues differently because of interpretative differences), second-instance amparos (against judicial rulings, called amparos directos, and against administrative acts and statutes, called amparos indirectos); a wide array of individual or ancillary questions within major proceedings; non-compliance proceedings; proceedings related to violations of the System of Fiscal Coordination; modifications or substitution of binding precedents ("jurisprudencia"); reviews of Judiciary Council decisions suspending or expelling judges; and participates in the appointments of the Justices of the Electoral Tribunal and the members of the Judiciary Council -among others. ${ }^{36}$

Both Courts come from a tradition where certiorari had no place and have extreme caseloads. Numbers are astronomical in Brazil (around 70,000 a year, if one includes liminal decisions, around 20,000 if departs from other criteria) $)^{37}$ and very high in Mexico (around 7,000 a year), although the Mexican court does better in terms of lag because of informal rules that put pressure on Justices to reasonably empty their drawers at the end of each year. Measures that in Brazil have helped control the number of cases are the dismissal of cases for "lack of general repercussion", the resolution of representative appeals that give guidance to lower Courts, or the creation of a system of summaries, called "súmulas", that if voted favorably are binding in character. In Mexico, where Supreme Court precedents are always binding under certain conditions, functionally similar devices are in place, like the categorical delegation of certain amparos in the Collegiate courts, the rule that allows review of direct amparos only if they contain questions of special importance and transcendence, or the rules set down in a General Agreement of 2015, which give further margin to the Court not to decide cases. ${ }^{38}$

\footnotetext{
${ }^{35}$ SILVA, Virgílio Afonso da. The Constitution of Brazil. A Contextual Analysis. Oxford: Hart Publishing, 2019 (forthcoming), p. 110-129.

${ }^{36}$ See a detailed description, with figures showing which areas of jurisdiction are responsible for what percentage of the caseload in POU GIMÉNEZ, Francisca. Constitutional Change and the Supreme Court Institutional Architecture: Decisional Indeterminacy as a Problem for Legitimacy. In: CASTAGNOLA, Andrea; NORIEGA, Saúl López (eds.). Judicial Politics in Mexico: The Supreme Court and the Transition to Democracy. New York: Routledge, 2017, p. 124-128.

${ }^{37}$ For an explanation about the dimension of the caseload, see MENDES, Conrado Hübner. The Supreme Federal Court of Brazil. In: JAKAB, András; DYEVRE, Arthur; ITZCOVICH, Giulio (eds). Comparative Constitutional Reasoning. Cambridge: Cambridge University Press, 2017, p. 126-127, and the works cited there, and SILVA, Virgílio Afonso da. The Constitution of Brazil. A Contextual Analysis. Oxford: Hart Publishing, 2019 (forthcoming), p. 112-113. For statistics in the Brazilian Court, see http://www.stf.jus.br/portal/cms/verTexto.asp?servico=estatistica

${ }^{38}$ Mexican Supreme Court, Acuerdo General 9/2015, June 8, 2015, on the rules about admissibility and processing of review in amparo directo (Diario Oficial de la Federación, June 12, 2015) Available at: <http://dof.gob.mx/ nota_detalle.php?codigo=5396550\&fecha=12/06/2015/>. Accessed on: 11 Oct. 2017.
} 
Both courts famously share, finally, a singular approach towards judicial communication and transparency. Both Courts have created Judicial Channels and broadcast Plenary deliberations and votes. ${ }^{39}$ Although there are details that vary in the decision-making protocols of the Courts, the general dynamics is largely analogous, as the main advantages and disadvantages of the system seem also to be so. The advantages are associated to the legitimacy gained by the Court in political systems that have been dominated by distrust and, in the context of Court that decide thousands of cases, to the additional visibility and availability that some of the decisions acquire, once they enter the radar of popular attention; the disadvantages are associated to deliberative losses (since in the most important cases, Justices simply arrive and present their position, rather than listen to others and be prepared to change their view), and to increased difficulties to reconstruct the reasoning behind the rulings. ${ }^{40}$

This analogous approach to judicial communication shouldn't be conflated, however, with the sharing of an identical public profile. ${ }^{41}$ Right after the enactment of the Constitution, the Supremo Tribunal Federal exhibited a sort of professionalized, politically temperate outlook, ${ }^{42}$ but over time it has asserted a strong degree of independence and has incredibly enlarged its powers and public presence. As scholars have repeatedly noted, it is difficult to think of a court having changed so radically in one or two decades. ${ }^{43}$ Although the bulk of the Brazilian docket is inconsequential cases, there is scarcely a public controversy that is not dealt with at the Tribunal. Recently, the Court has dealt with criminal proceedings on corruption cases that touch the core of the political system, like the famous Mensalão case, or then even more politically charged

\footnotetext{
${ }^{39}$ For an overview of relations between courts and the press and the wider public worldwide, including contributions on the publicity of deliberations in Brazil and Mexico, see DAVIS, Richard; TARAS, David. (eds.). Justices and Journalists: The Global Perspective. New York: Cambridge University Press, 2017.

${ }^{40}$ See MENDES, Conrado Hübner. The Supreme Federal Court of Brazil. In: JAKAB, András; DYEVRE, Arthur; ITZCOVICH, Giulio (eds). Comparative Constitutional Reasoning. Cambridge: Cambridge University Press, 2017, and SILVA, Virgílio Afonso da. 'Deciding without Deliberating'. International Journal of Constitutional Law, v. 11 n. 3, p. 557-584, 2013.

${ }^{41}$ For an interesting comparative exercise between the two courts that warns about the limits of institutional commonalities in understanding their different positions in political system, see BENVINDO, Juliano Zaiden; GONÇALVES, Fernando José Acunha. O papel da política na atuação das Corte Supremas: Uma comparaçao entre Brasil e México. Novos Estudos CEBRAP, v. 37, n. 1, p. 57-79, 2018.

${ }^{42}$ In her study of the relations of between Courts and political branches in Brazil and Argentina in the domain of economic policy, Diana Kapiszewski (building on Mill's "differences" method and taking for granted many similarities between the two Courts) suggests explanation for the different patterns may be found in the different "character" of the courts: more professional, "statesman" Court in the Brazilian case (a stable partner of the other branches), and a more political and unstable in the Argentinian one. See KAPISZEWSKI, Diana. Economic Governance on Trial: High Courts and Elected Leaders in Argentina and Brazil. Latin American Politics and Society, v. 55, n. 4, p. 47-73, 2013. This is probably very different at this point.

${ }^{43}$ MENDES, Conrado Hübner. The Supreme Federal Court of Brazil. In: JAKAB, András; DYEVRE, Arthur; ITZ$\mathrm{COVICH}$, Giulio (eds). Comparative Constitutional Reasoning. Cambridge: Cambridge University Press, 2017., p. 115-116, and SILVA, Virgílio Afonso da. The Constitution of Brazil. A Contextual Analysis. Oxford: Hart Publishing, 2019 (forthcoming), p. 96.
} 
Lava Jato case. ${ }^{44}$ The Mexican Court has, by contrast, preserved a contained role. From time to time, the Court gains public attention -it occurred, for instance, when it validated the first-trimester legalization of abortion in Mexico City, when it changed due process criteria in a famous case involving accusations against a French citizen, or when it authorized the recreational use of marihuana- but it hasn't systematically situated itself at the center of the public stage. This may be explained in part by the fact limited access to justice means that fewer things arrive at the Court. But in part it seems a consequence of a hesitant attitude that seems to have gained space these few last years. At the moment, several politically-charged cases - like the abstract challenge against the Interior Security Act - are pending, and the Court, maybe attentive to changes in the climate in view of the incoming Presidential election, stays passive. For some reason, the Mexican Court has not capitalized on the very profound discontentment with the political system that prevails in Mexican society. It is much closer to the other branches and far less politically disruptive than its Brazilian counterpart.

\section{A DIS-ANALOGY: RIGHTS REVOLUTION VERSUS RIGHTS FRUS- TRATION}

As some authors have underlined, in post-dictatorial Argentina and Brazil, people initially turned to the courts to fight against economic deprivation. ${ }^{45}$ They then used the panoply of institutional channels at their disposal to seek guarantee of many other constitutional entitlements. The reach and the intensity of constitutional rights litigation in Brazil are readily visible in any fast survey of the literature, where we find assessments of what is, by all accounts, a robust practice with regards pretty much all constitutionally protected entitlements.

The right to health is no doubt one of the areas where litigation in Brazil -and academic discussion about its effects - has been more intense. Even outside the country, the debate is well known among those who argue that the judicialization of health has not served the interests of those in most need and has increased inequalities, and those that show that, at least in some areas of the country, litigation has helped poor and older individuals which do not leave in metropolitan areas, who depend on the state to provide them with legal representation, and who had been denied medicines

\footnotetext{
${ }^{44}$ On the way the Court has changed its former criminal law doctrines in recent high-profile corruption cases, see PRADO, Mariana Mota; MACHADO, Marta. The Promises and Perils of Using Criminal Law to Fight Corruption: The Lava Jato Case. Paper presented at Seminario en Latinoamérica de Teoría Constitucional y Política 2018, San Juan de Puerto Rico, 2018.

${ }^{45}$ KAPISZEWSKI, Diana. Economic Governance on Trial: High Courts and Elected Leaders in Argentina and Brazil. Latin American Politics and Society, v. 55, n. 4, p. 47, 2013.
} 
and services already listed on governmental formularies and plans. ${ }^{46}$ Ana Paula de Barcellos has explored, on her part, how public law litigation has operated in Brazil in the shaping of public policy regarding some of the central determinants of health: sanitation policies. Her study covers 258 Court orders, issued in a period of ten years. She concludes that the Brazilian judiciary has been in general willing to improve access to sanitation services, though suits are very far from covering an important percentage of the municipalities with severe problems or from reaching the poorest cities. ${ }^{47}$ Also worth mentioning, because of its great visibility outside, is experience with the judicialization of environmental claims, ${ }^{48}$ which may be prolonged in a more general practice associated to the enforcement of collective and diffuse rights and interests. ${ }^{49}$ While a detailed account of rights enforcement dynamics in Brazil would require far more than these spare examples, I believe the underlying premise is not contentious: Brazilian constitutional dynamics under the 1988 Constitution have definitely included an energetic practice of constitutional rights enforcement, under the lead of the Supremo Tribunal. As Conrado Hübner Mendes remarks:

The Supremo Tribunal Federal has been portrayed as one of the responsible actors, if not the foremost, for the main achievements in fundamental rights by Brazilian democracy since the beginning of the 2000s. Paradigmatic decisions taken during this period include the permission of marriage for same-sex couples, the confirmation of affirmative action programs, the authorization of the abortion of anencephalic fetuses, the validation of stem-cell research, intervention in health rights policies, and public officals' right to strike, to mention but a few. ${ }^{50}$

There may be discussion on what rights enforcement has really meant in terms of problem-solving and social transformation, but not on the fact the Brazilian bill of

\footnotetext{
${ }^{46}$ Compare FERRAZ, Ottavio L. Mota. The right to health in the courts of Brazil: Worsening health inequalities? Health and Human Rights, v. 11, p. 33-45, 2009, and DA SILVA, Virgilio Alfonso; TERRAZAS, Fernanda Vargas. Claiming the Right to Health in Brazilian Courts: The exclusion of the already excluded? Law and Social Inquiry, v. 36 n. 4, p. 825-853, 2011, to BIEHL, João; SOCAL, Mariana P.; AMON, Joseph J. The judicialization of health and the quest for state accountability: Evidence from 1262 lawsuits of access to medicines in Southern Brazil. Health and Human Rights Journal v. 18, n. 1, p. 209-220, 2016.

${ }^{47}$ BARCELLOS, Ana Paula de. Sanitation Rights, Public Law Litigation, and Inequality: A Case Study from Brazil. Health and Human Rights, v. 16, n. 2, p. 35-46. 2014.

${ }^{48}$ See MCALLISTER, Lesley. Making Law Matter: Environmental Protection \& Legal Institutions in Brazil. Stanford: Stanford University Press, 2008, and MCALLISTER, Lesley K. Environmental Advocacy Litigation in Brazil and the United States. Journal of Comparative Law v. 6, n. 2, p. 203-219, 2011.

${ }^{49}$ For a classical account about Brazilian class actions, the different ways of enforcing collective and diffuse claims in the country, with remarks based on the experience of litigation, see GIDI, Antonio. Class Actions in Brazil - A Model for Civil Law Countries. American Journal of Comparative Law, v. 51, p. 311-408, 2013.

${ }^{50}$ MENDES, Conrado Hübner. The Supreme Federal Court of Brazil. In: JAKAB, András; DYEVRE, Arthur; ITZCOVICH, Giulio (eds). Comparative Constitutional Reasoning. Cambridge: Cambridge University Press, 2017, p. 117.
} 
rights has become a sprightly collective enterprise that continuously engages citizens, judges, private actors and political and administrative branches.

In Mexico, Courts have accused fewer pressures on the part of the citizenry. Access to justice continues to be extremely limited. For sure, the times when all the cases reaching the Supreme Court involved mere "legality" controversies (as opposed to constitutional ones) are now behind, and the Court has issued important new criteria in several rights-related domains. But if we analyze these developments against the backdrop of a 120-million people country immersed in deprivation, poverty and state collapse, the reach and the low intensity of judicialization are hard to believe. In the area we have focused in the case of Brazil -health - the scenario couldn't be more contrasting. In a study where they search for all Supreme Court amparos possibly related with the judicialization of the right to health decided between 2011 and 2017 —after the allegedly rights-booming human rights reform - Cobo and Charvel find only 22 amparos, 12 of which are tort, malpractice cases. ${ }^{51}$ An examination of the remaining $10^{52}$ reveal a scenario in which the majority of petitioners are corporations, not citizens, elevating claims that have little to do with health rights, focusing instead on opposing health-protective regulations on the basis of economic freedom. Most of all, the number of cases is simply ridiculous. Even if granting that there are some health-related issues dealt with in procedural channels other than amparo -abortion and the morning-after, which involved health-related aspects, decided for instance as acciones de inconstucionalidad and controversias-; even granting that there might be criteria on other amparos that impinge on the matter which are not captured by the study's selection focus; and even granting that something might be happening at the level of Circuit Courts - yet in the extremely vertical Mexican judiciary little happens if it does not happen before in the Supreme Court - the numbers are anomalously low.

While the monitoring, systematization and critical assessment of judicial developments in Mexico is grossly insufficient, it is not risky to suggest that the scenario we find with regards health rights is the scenario we equally find in most rights-related

\footnotetext{
${ }^{51} \mathrm{COBO}$, Fernanda; CHARVEL, Sofía. The Mexican Supreme Court and the right to health: its problematic interpretations. Manuscript on file with author, 2018, p. 3-4.

${ }^{52}$ The specific issues are the following: a supermarket that challenges the regulation controlling the production and distribution of tobacco; a restaurant that challenges anti-tobacco exposure regulations; a group of HIV-positive persons that claim to receive medical attention in a building separate from the other patients to be safer from infections; a pharmaceutical company that claims its right to participate in a new drug registration proceedings; a person that challenges the regulations that prohibit vending of electronic cigarettes; a group of persons that challenge the prohibition to make recreational use of marijuana; a person that asks the public system to provide her with an expensive orphan drug; a corporation that challenges the prohibition to distribute soda drinks in high schools; a person that asks for drugs included in the Basic Package; and a homeless person that denounces State omissions in satisfying his basic needs. COBO, Fernanda; CHARVEL, Sofía. The Mexican Supreme Court and the right to health: its problematic interpretations. Manuscript, on file with author, 2018. p. 9-10.
} 
areas. $^{53}$ By all accounts, there has been no "rights-revolution" in Mexico. ${ }^{54}$ There is no debate in Mexico about inter-branch tensions derived of mass litigation of individual or collective claims. Most notably of all, in Mexico the structural, "experimental" judgments that have so famously occupied apex Courts in other Latin American countries are lacking. ${ }^{55}$ The Supreme Court of Mexico remains within the confines of classical individual, bi-polar constitutional litigation, with "strong-review" classical techniques. There are no structural orders in the rulings; there is no monitoring; there are no "dialogic" solutions.

While this analysis is limited to register the patterns without much chance to deepen on possible explanations, there are elements that -in view of the literature on the determinants of judicialization-clearly distinguish the situation in the two countries. Some of these elements are "offer"-based and account for the attitude and action of the Courts. Others are "medium"-based and include not only the simplicity or complexity of rights-protecting channels, but also features like the regulation of precautionary measures, ${ }^{56}$ or the mechanisms available to assure obedience to the Court. ${ }^{57}$ Others, perhaps crucially, are "demand"- based. In this regard, the strength of public interest litigation in Brazil and its merely incipient nature in Mexico can surely explain many things. The 1988 Constitution created anew the Public Defender's Office and transformed the Public Ministry into a powerful, prestigious office with full guarantees of independence. As the literature has remarked, the Public Ministry has become "an institution (...) in charge of promoting, defending and expanding the public sphere in country," ${ }^{\prime \prime 8}$ and has played a crucial role in defending individual and collective

\footnotetext{
${ }^{53}$ For an overview of criteria by scholars and officials closely familiar with Mexican judicial dynamics, derived however from a non-systematic monitoring, see COSSÍO DÍAZ, José Ramón (coord.). Constitución Política de los Estados Unidos Mexicanos Comentada. Mexico City: Tirant lo Blanch, 2017

${ }^{54}$ See the contributions included in CASTAGNOLA, Andrea; NORIEGA, Saúl López (eds.). Judicial Politics in Mexico: The Supreme Court and the Transition to Democracy. New York: Routledge, 2017.

${ }^{55}$ For a survey of second-generation dialogical or "experimentalist" structural rulings in Latin America, see BERGALLO, Paola. Justicia y experimentalismo: la función remedial del poder judicial en el litigio de derecho público en Argentina. In: Derecho y pobreza SELA, 2005. Available at: <http://digitalcommons.law.yale.edu/ yls_sela/45/>. Accessed on: 11 Oct. 2017, and ABRAMOVICH, Víctor; PAUTASSI, Laura. La revisión judicial de las políticas sociales. Buenos Aires: Editores del Puerto, 2008., RODRÍGUEZ-GARAVITO, César. (ed.). Law and Society in Latin America. A New Map. New York: Routledge, 2015, or several of the contributions in ALVIAR, Helena; KLARE, Karl; WILLIAMS, Lucy A. (eds.). Social and Economic Rights in Theory and Practice: Critical Inquiries. Oxon and New York: Routledge, 2015.

${ }^{56}$ In Mexico they are adopted by lower judges, while the Supremo Tribunal flexibly uses the interlocutory injunction. ROSENN, Keith S. Recent Important Decisions by the Brazilian Supreme Court. The University of Miami Inter-American Law Review, v. 45 n. 2, p. 297-334, 2013, p. 317.

${ }^{57}$ SILVA, Virgílio Afonso da. The Constitution of Brazil. A Contextual Analysis. Oxford: Hart Publishing, 2019 (forthcoming), p. 97.

${ }^{58}$ FERNANDES, Edesio; MCALLISTER, Lesley K. Making Law Matter: Environmental protection and Legal Institutions in Brazil. Journal of Latin American Studies, v. 41, n. 3, p. 629-630, 2009, p. 629.
} 
fundamental rights and broadening access to justice. ${ }^{59}$ In contrast to the situation in the United States, in Brazil most environmental suits are filed by the Public Ministry, ${ }^{60}$ and the same has occurred with regards collective interests/class actions. ${ }^{61}$

\section{CONCLUSION}

Brazil has been compared to other countries more often than to Mexico. Studies in comparative constitutional change are maybe a first sign that the situation is starting to change. ${ }^{62}$ This contribution has meant to suggest to what extent deepening along that comparative path is promising, taking the occasion to explore and assess some aspects of the constitutional systems and the constitutional dynamics that obtain in the two countries.

For sure, our brief focus has left many dimensions of constitutional life outside -there is no need to insist on the limitations of an analysis that does not address the study of federalism or the division of powers, nor articulates rights protection developments with these other dimensions. But it already gestures to features that might have been more difficult to identify without the comparative exercise.

The exercise confirms, in my view, a pessimistic forecast with regards to Mexico. Even with the limitations of a constitution-making process that was not perfect, Brazil is a country where thirty years of constitutional longevity have given both citizens and political actors the opportunity to appropriate the Constitution and use it intensively to manage collective problems -if not, admittedly, to solve them. In Mexico, by contrast, spending one hundred years without the experience of an expanded, intense constitutional moment has taken a heavy toll that is not finding compensation in terms of output legitimacy of the Constitution. The Mexican constitution is a clumsy collection of tools, some of them interesting when viewed in isolation, but un-articulated into a collective political project perceived by citizens as inclusive and normatively aligned with their right and needs. The judiciary — the single actor that in so many counties helps the constitutional legitimacy alchemy occur - has not been helpful enough, and

\footnotetext{
${ }^{59}$ SILVA, Virgílio Afonso da. The Constitution of Brazil. A Contextual Analysis. Oxford: Hart Publishing, 2019 (forthcoming), p. 134-135.

${ }^{60}$ MCALLISTER, Lesley K. Environmental Advocacy Litigation in Brazil and the United States. Journal of Comparative Law v. 6, n. 2, p. 203, 2011.

${ }^{61} \mathrm{GIDI}$, Antonio. Class Actions in Brazil - A Model for Civil Law Countries. American Journal of Comparative Law, v. 51, p. 379-382, 2013.

${ }^{62}$ ALBERT, Richard; BERNAL, Carlos; BENVINDO, Juliano Zaiden (eds.). Constitutional Change and Transformation in Latin America. Oxford: Hart Publishing, 2019 (forthcoming), and POU GIMÉNEZ, Francisca; POZASLOYO, Andrea. Are Constitutional Amendment and Judicial Review Substitutes? Unexpected Lessons from Mexico and Brazil. Paper presented at the Law and Society Annual Meeting, Mexico City, 2017.
} 
the country is now witnessing authoritarian regressions ${ }^{63}$ and an unstoppable rise in popular frustration.

Although I am not in a position to advance strong conclusions, I dare say that when viewed under the comparative light that comes from Mexico, Brazil does look good. At its thirtieth anniversary, the 1988 Constitution enjoys a solid legitimacy that in Mexico is missing. The analysis suggests, perhaps, that even in countries where institutional design (and path-dependence) confer an extensive array of powers and responsibilities on courts, unbridled activism is not inevitable. A pressing question in the Brazilian context - yet one that can only be answered after a comprehensive survey, not after the sort of preliminary, selective, and exclusively "inviting" analysis we have pursued here- would probably be in what conditions the role now displayed by the Supremo Tribunal Federal is democratically sustainable.

\section{REFERENCES}

ABRAMOVICH, Víctor; PAUTASSI, Laura. La revisión judicial de las políticas sociales. Buenos Aires: Editores del Puerto, 2008.

ALTERIO, Micaela. NIEMBRO, Roberto. Constitutional Culture and Democracy in Mexico: A Critical View of the 100-Year-Old Mexican Constitution. In: GRABER, Mark; LEVINSON, Sanford; TUSHNET, Mark. (eds.). Constitutional Democracy in Crisis? New York: Oxford University Press, 2018.

ALVIAR, Helena; KLARE, Karl; WILLIAMS, Lucy A. (eds.). Social and Economic Rights in Theory and Practice: Critical Inquiries. Oxon and New York: Routledge, 2015.

ARGUELHES, Diego Werneck; RIBEIRO, Leandro Molhano. 'The Court, it is I'? Individual judicial powers in the Brazilian Supreme Court and their implications for constitutional theory. Global Constitutionalism, v. 7, n. 2, p. 236-262, 2018.

BARBOSA, Leonardo Augusto de Andrade. Legislative Process and Constitutional Change in Brazil: On the Pathologies of the Procedure for Amending the 1988 Constitution. In: ALBERT, Richard; BERNAL, Carlos; BENVINDO, Juliano Zaiden (eds.). Constitutional Change and Transformation in Latin America. Oxford: Hart Publishing, 2019 (forthcoming).

BARCELLOS, Ana Paula de. Sanitation Rights, Public Law Litigation, and Inequality: A Case Study from Brazil. Health and Human Rights, v. 16, n. 2, p. 35-46, 2014.

BENVINDO, Juliano Zaiden. The Brazilian Constitutional Amendment Rate: A Culture of Change? International Journal of Constitutional Law Blog. Available at: <http://www.iconnectblog. com/2016/08/the-brazilian-constitutional-amendment-rate-a-culture-of-change/>. Accessed on: 11 Oct. 2017.

${ }^{63}$ ALTERIO, Micaela. NIEMBRO, Roberto. Constitutional Culture and Democracy in Mexico: A Critical View of the 100-Year-Old Mexican Constitution. In: GRABER, Mark; LEVINSON, Sanford; TUSHNET, Mark. (eds.). Constitutional Democracy in Crisis? New York: Oxford University Press, 2018. 
BENVINDO, Juliano Zaiden; GONÇALVES, Fernando José Acunha. O papel da política na atuação das Corte Supremas: Uma comparaçao entre Brasil e México. Novos Estudos CEBRAP, v. 37, n. 1, p. 57-79, 2018.

BEGALLO, Paola. Justicia y experimentalismo: la función remedial del poder judicial en el litigio de derecho público en Argentina. In: Derecho y pobreza SELA, 2005. Available at: $<$ http://digitalcommons.law.yale.edu/yls_sela/45/>. Accessed on: 11 Oct. 2017.

BIEHL, João; SOCAL, Mariana P.; AMON, Joseph J. The judicialization of health and the quest for state accountability: Evidence from 1262 lawsuits of access to medicines in Southern Brazil. Health and Human Rights Journal, v. 18, n. 1, p. 209-220, 2016.

BOGDANDY, Armin von. MAC-GREGOR, Eduardo Ferrer; ANTONIAZZI, Mariela Morales; PIOVESAN, Flávia (eds.); SOLEY, Ximena (managing ed.). Transformative Constitutionalism in Latin America: The Emergence of a New lus Commune. Oxford: Oxford University Press, 2017.

CASAR, María Amparo; MARVÁN, Ignacio. (eds.). Reformar sin mayorías. La dinámica del cambio constitucional en México 1997-2012. Mexico City: Taurus, 2014.

COBO, Fernanda; CHARVEL, Sofía. The Mexican Supreme Court and the right to health: its problematic interpretations. Unpublished paper, on file with author, 2018.

COSSÍO DÍAZ, José Ramón. Sistemas y modelos de control constitucional en México. Mexico City: IIJ UNAM, 2013.

COSSÍO DÍAZ, José Ramón (coord.). Constitución Política de los Estados Unidos Mexicanos Comentada. Mexico City: Tirant lo Blanch, 2017.

COSTA, Alexandre Araújo; ASSUNÇÃO, Guilherme Sena de. On the Limits of the Supermajority Rule: The Brazilian Experience on Using Constitutional Amendments to Circumvent the System of Checks and Balances. In: ALBERT, Richard; BERNAL, Carlos; BENVINDO, Juliano Zaiden (eds.). Constitutional Change and Transformation in Latin America. Oxford: Hart Publishing, 2019 (forthcoming).

DAVIS, Richard; TARAS, David. (eds.). Justices and Journalists. The Global Perspective. New York: Cambridge University Press, 2017.

FERNANDES, Edesio; MC ALLISTER, Lesley K. Making Law Matter: Environmental protection and Legal Institutions in Brazil. Journal of Latin American Studies, v. 41, n. 3, p. 629-630, 2009.

FERRAZ, Ottavio L. Mota. The right to health in the courts of Brazil: Worsening health inequalities? Health and Human Rights, v. 11, p. 33-45, 2009.

GIDI, Antonio. Class Actions in Brazil - A Model for Civil Law Countries. American Journal of Comparative Law, v. 51, p. 311-408, 2013. 
HIRSCHL, Ran. On the blurred methodological matrix of comparative constitutional law. In: CHOUDHRY, Sujit. (ed.). The migration of constitutional ideas. New York: Cambridge University Press, 1995.

KAPISZEWSKI, Diana. How Courts Work: Institutions, Culture and the Brazilian Supremo Tribunal Federal. In: SIEDER, Rachel; HUNNEUS, Alexandra; COUSO, Javier (eds.). Cultures of Legality. Judicialization and Political Activism in Latin America. New York, Cambridge University Press, 2010.

KAPISZEWSKI, Diana. Economic Governance on Trial: High Courts and Elected Leaders in Argentina and Brazil. Latin American Politics and Society, v. 55, n. 4, p. 47-73, 2013.

MARVÁN LABORDE, Ignacio. Cómo hicieron la Constitución de 1917. Mexico City, CIDE, 2017.

MCALLISTER, Lesley. Making Law Matter: Environmental Protection \& Legal Institutions in Brazil. Stanford: Stanford University Press, 2008.

MCALLISTER, Lesley K. Environmental Advocacy Litigation in Brazil and the United States. Journal of Comparative Law, v. 6, n. 2, p. 203-219, 2011.

MENDES, Conrado Hübner. The Supreme Federal Court of Brazil. In: JAKAB, András; DYEVRE, Arthur; ITZCOVICH, Giulio (eds). Comparative Constitutional Reasoning. Cambridge: Cambridge University Press, 2017.

PAZ, Octavio. El laberinto de la soledad. Mexico City: Fondo de Cultura Económica, 1994.

POU GIMÉNEZ, Francisca. Constitutional Change and the Supreme Court Institutional Architecture: Decisional Indeterminacy as a Problem for Legitimacy. In: CASTAGNOLA, Andrea; NORIEGA, Saúl López (eds.). Judicial Politics in Mexico: The Supreme Court and the Transition to Democracy. New York: Routledge, 2017.

POU GIMÉNEZ, Francisca; POZAS-LOYO, Andrea. Are Constitutional Amendment and Judicial Review Substitutes? Unexpected Lessons from Mexico and Brazil. Paper presented at Law and Society Annual Meeting 2017, Mexico City, 2017.

POU GIMÉNEZ, Francisca; POZAS-LOYO, Andrea. The Paradox of Mexican Constitutional Hyper -reformism: Enabling Peaceful Transition while Blocking Democratic Consolidation. In: ALBERT, Richard; BERNAL, Carlos; BENVINDO, Juliano Zaiden (eds.). Constitutional Change and Transformation in Latin America. Oxford: Hart Publishing, 2019 (forthcoming).

POU GIMÉNEZ, Francisca; RODILES, Alejandro. Mexico. In: PALOMBINO, Fulvio (ed.). Duelling for Supremacy: International Law vs. National Fundamental Principles. Cambridge: Cambridge University Press, 2019 (forthcoming).

POZAS-LOYO, Andrea; RIOS FIGUEROA, Julio. Anatomy of an Informal Institution: Patronage Networks and the 'Gentlemen's Pact' in the Mexican Federal Judiciary, 1917-1994. International Political Science Review. vol. 39, n. 5, p. 647-661, 2018. 
PRADO, Mariana Mota; MACHADO, Marta. The Promises and Perils of Using Criminal Law to Fight Corruption: The Lava Jato Case. Paper presented at Seminario en Latinoamérica de Teoría Constitucional y Política (SELA) 2018, San Juan de Puerto Rico, 2018.

ROSENN, Keith S. Recent Important Decisions by the Brazilian Supreme Court. The University of Miami Inter-American Law Review, v. 45 n. 2, p. 297-334, 2013.

ROSENN, Keith S. Procedural Protection of Constitutional Rights in Brazil. The American Journal of Comparative Law, v. 59 n.4, p. 1009-1050, 2011

SALGADO, Eneida Desiree; CHAGAS, Carolina Alves das. The Judicial Review of Constitutional Amendments in Brazil and the Super-Countermajoritarian Role of the Brazilian Supreme Court. In: ALBERT, Richard; BERNAL, Carlos; BENVINDO, Juliano Zaiden (eds.). Constitutional Change and Transformation in Latin America. Oxford: Hart Publishing, 2019 (forthcoming).

SILVA, Virgílio Afonso da. The Constitution of Brazil. A Contextual Analysis. Oxford: Hart Publishing, 2019 (forthcoming).

SILVA, Virgílio Afonso da. Deciding without Deliberating. International Journal of Constitutional Law, v. 11, n. 3, p. 557-584, 2013.

SILVA, Virgilio Alfonso da; TERRAZAS, Fernanda Vargas. Claiming the Right to Health in Brazilian Courts: The exclusion of the already excluded? Law and Social Inquiry, v. 36 n. 4, p. 825-853, 2011.

SILVA GARCÍA, Fernando. Derechos humanos y restricciones constitucionales: ¿reforma constitucional del futuro vs. interpretación constitucional del pasado? (comentario a la CT 293/2011 del Pleno de la SCJN). Cuestiones constitucionales, n. 30, p. 251-272, 2014.

TSCHORNE, Samuel I. The "legitimacy crisis" and the "constitutional problem" in Chile: what is left? Paper presented at Seminario en Latinoamérica de Teoría Constitucional y Política (SELA) 2018, San Juan de Puerto Rico, 2018.

UNGER, Roberto Mangabeira. Democracy realized. The progressive alternative. London: Verso, 1998.

UPRIMNY, Rodrigo. The recent transformation of constitutional law in Latin America. Trends and challenges. In: RODRÍGUEZ-GARAVITO, César. (ed.). Law and Society in Latin America. A New Map. New York: Routledge, 2015.

YRIGOYEN FAJARDO, Raquel Z. The panorama of pluralist constitutionalism: from multiculturalism to decolonization. In: RODRÍGUEZ-GARAVITO, César. (ed.). Law and Society in Latin America. A New Map. New York: Routledge, 2015.

VELASCO, Mariana. Mexico's Constitutional Entrenchment Mirage: The Political Sources of Hyper-Reformism. In: ALBERT, Richard; BERNAL, Carlos; BENVINDO, Juliano Zaiden (eds.). 